に3〜4世代がくりかえされる可能性が認められた。な お，世代の長さは温度が高いほど短くなる傾向がみられ た。

2）八キダメギクの開花順序は集散花序に属し，1 株 の 1 世代に扔ける開花数は 13,400 個前後， 1 花の種子 数は 30 粒前後, 後者を前者に乗ずれば約 40 万粒とな り, 雑草のなかで種子の生産量の多い草種であることが 明らかとなった。

3）八キダメギクの生育は，発芽時期の差によって異 なり，草丈および葉面積の拡大速度は，春および秋に劣 り夏にまさることが認められ，八キダメギクの生育，発 芽から開花までの日数, 種子の成熟に要する日数がいず れも高温によって短縮されることが認められた。
4）八キダメギクは明発芽種子型に属することが認め られた。

\section{引用 文 献}

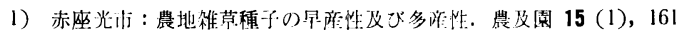
$\sim 162$ (1940).

2) Ivany, J. A. and Sweet, R. D.: Germination, growth development, and control of Galinsoga. weed Sci. 21, 4l 45 (1973).

3）笠原安夫: 雑草種子の発芽の研究. 第 2 報 (2) 発芽伅及注す变 温の影響；（3）癹芽床と発芽との関係。農及園 16 ( 3 ), 36 44 (1941).

4）片岡孝義・ 川嶋良一：農学大辞典. 養孯堂, 243 268 (1968).

5）牧野富太郎：牧野新日木植物図鑑。北隆館, 639 (1962).

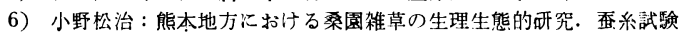
場報告 20 (3)，259 290（1966）。

(1976 年 3 月 8 日受付)

\title{
Ecological Studies on Weeds in Mulberry Fields
}

2. Auto-ecology of Galinsoga parviflora Cav.

\section{Youzo UsamI}

Sericultural Experiment Station, Hino-shi, Tokyo

\section{Summary}

For the relevant planning of weed control in mulberry field, information on auto-ecology of Galinsoga Parviflora Cav. was investigated in the cource of growing season, with regard to alternation of generations, florescence, seed production and germination ability of seeds.

Experiments were carrid out in the Hino-mulberry field (Hino-shi) for three years from 1971.

The results were as follows;

Germination of Galinsoga was observed from late March till early November during which 3 to 4 times of alternation of generations took place.

13, 400 achenes were enumerated per plant that bore as much as 400,000 seeds. Stem height and leaf area expanded more prosperously in summer than in spring or autumn, accordingly, growth of Galinsoga being dependent on season of germination. High temperature seemed to urge growth, florescence and maturity.

It was recognized that Galinsoga belonged to a type having light-sensitive seed.

\section{ベンチオカーブとシメトリンにたいするイネの抵抗性の品種間差異}

\author{
宇都宮大学雑草防除研究施設 一 前 宣 正
}

現在, ベンチオカーブ $[S$-(4-chlorobenzyl) $N, N$ diethyl thiolcarbamate] は単剂あるいはシメトリン [2-methylthio 4,6-bis (ethylamino) $s$-triazine]また は CNP $\left[2,4,6\right.$-trichloro $4^{\prime}$-nitro diphenylether $] な$ 
どとの混命剂として,わが国をはじめ世界の水稲栽培地 帯において広く利用され², その適用は多数のイネ品種 に及んでいる。

除草剤にたいする作物の抵抗性の品種間差異に関して は，すでに多くの報告がある ${ }^{2,3,4)}$ 。とくにシマジンンや アトラジンにたいするトウモロコシの品種間差異5,6), DCPA にたいするイネの品種間差異7), バーバンにたい するオオムギの品種間差異 ${ }^{8}$ 等は遺伝学的に分析され, 遺伝子によって支配されることが報告されている。

重松ら ${ }^{9)}$ はインド型の IR-8 が日本型の品種にくらべ てベンチオカーブに耐性の弱いことを報告し，KIM ら ${ }^{10)}$ はベンチオカーブとシメトリンの混合剤が日本型の品種 よりもインド型と日本型の交配品種にたいして薬害の強 いことを述べている。

そこで，筆者は，わが国および諸外国において栽㥉さ れている 34 品種のイネを供試し, ベンチオカーブとシ メトリンにたいする品種間抵抗性に関する検討を行。 た。この報告は, その結果をとりまと めたものである。なお, 本報告の一部 は, 日本雑草防除研究会第 14 回講演 会で発表した ${ }^{11) 。 ~}$

本実験は, 宇都宮大学雑草防除研究 施設長竹松哲夫教授, 同施設近内誠登 教授の懇切な御指導と御助言のもとに 実施した。ここに謹しんで謝意を表す るものである。

\section{1. 実験材料と方法}

1974 年 7 月 10 日, $200 \mathrm{~cm}^{2}$ ポット に沖積埴㙵土を入れ, $3 \mathrm{~cm}$ 湛水後, 34 品種のイネの種子および子葉䩗期の苗 （種子を $28^{\circ} \mathrm{C}$ 定温器で発芽させ, 発芽 の早い品種は一時 $5^{\circ} \mathrm{C}$ の条件下に置 いて各品種の生育を揃え, 子葉䩗が $0.5 \sim 0.8 \mathrm{~cm}$ に伸長したもの) を 30 個 体播き, 2 葉期の苗 10 本を $1 \mathrm{~cm}$ の深 さに移植した。

薬剤はベンチオカーブ乳剂 (50\%) とシメトリン水和剤 $(50 \%)$ を用い て,イネの播種および移植直後に希釈 薬液をピペットで水面に滴下処理し た。ベンチオカーブは, 34 品種のイネ にたいして，発芽前と子葉䩗期に 5 $\mathrm{g} / \mathrm{a}, 2$ 葉期に $100 \mathrm{~g} / \mathrm{a}$ の処理を行い, さらに発芽前と 2 葉期の IR- 8 および
ニホンバレにたいして 1. 25 640 g/a の処理を行った。 シメトリンは, 発芽前と 2 葉期の IR-8 およびニホンバ レにたいして0.625〜 40 g/a の処理を行った。

処理ホットは野外に置き, 適時給水して水深を約 $3 \mathrm{~cm}$ に保ち, 降雨を避けた。実験は 2 連制で行った。夹験期 間中の気温は表 1 の通りであった。

表 1 実験期間の平均気温一半旬平均一

\begin{tabular}{c|c|c|c}
\hline 7 月 $10 \sim 15$ & $16 \sim 20$ & $21 \sim 25$ & $26 \sim 30 !$ \\
\hline $26.6^{\circ} \mathrm{C}$ & 27.3 & 26.1 & 25.1 \\
\hline
\end{tabular}

調査は, 薬剂処理 20 日後にイネの生体重測定によっ て行った。

\section{2. 実験結果と考察}

図 1 は，34 品種のイネのベンチオカーブにたいする 耐性反応を示したものである。発芽前および子葉䩗期に おける生体重抑制率をみると, 日本, アメリカ, イタリ

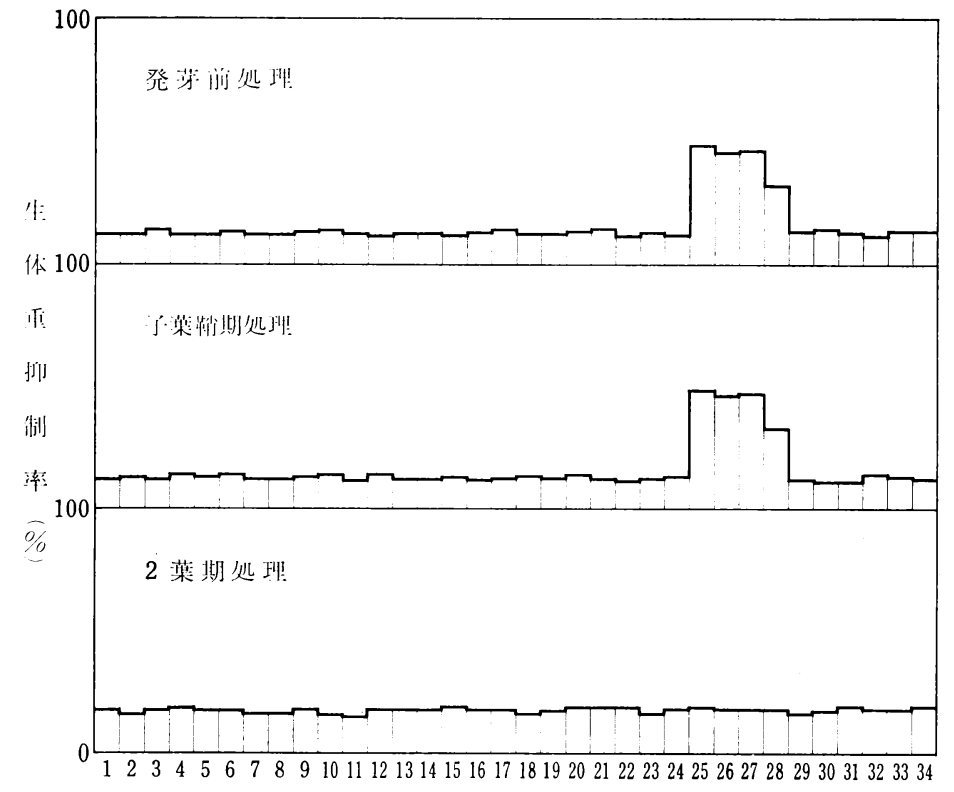

図1 ベンチオカーブにたいするイネの品種別抵抗性

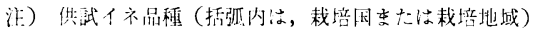

\begin{tabular}{|c|c|c|}
\hline 1. ムッニシキ(口木) & 13. 北陵 90 号（日木） & 25. IR-8（察南アジア） \\
\hline 2. キヨニシキ(ク) & 14. ックシバレ(ク) & 26. Leuang Tawng (タイ) \\
\hline フシシ & 15. ク $\because z$ ウ ( " ) & 27. $\mathrm{C} 4-63$ (フィリピソ) \\
\hline$V 1 \times$ & 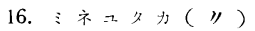 & 28. Taichung Native (台湾) \\
\hline ササニシキ & 17. $\vdash \equiv y$ & 29. Tainan-3 (" ) \\
\hline ホウネンワセ( & 18. アソミノリ & 30. Bluebelle (アメり\%) \\
\hline 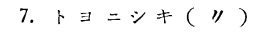 & 19. 南海 55 号 (”) & 31. Bluebonnet ( $")$ \\
\hline コシヒカり(ク) & 20.レイ末 & 32. Caluro (" \\
\hline ヨモマサリ( & 21. ニホンバ & 33. Calrose ( \\
\hline クサブ & 22. キンマ & 34. Rafaello (イタリア) \\
\hline 農 林 29 & 23. & \\
\hline 農 林 35 & 24. & \\
\hline
\end{tabular}


アで栽培されている品種および台湾の Tainan-3（蓬来 米の一品種）では $11 \sim 14 \%$ の範囲であるが，インド型 の IR-8, Leuang Tawng, C4-63 および Taichung Native では 30 50\% の範囲であった。一方, 2 葉期に おける生体重抑制率は, 供試したすべての品種において 6〜 9\%の範囲であった。すなわち, ベンチオカーブに たいするイネの抵抗性は, 品種によって異なり, インド 型の品種は日本, アメリカ, イタリアなどで栽培されて いる品種よりも抵抗性の低いことが認められた。

除草剤にたいするイネの抵抗性の品種間差異は, 発芽 や生育速度の違いに基ゔく薬剤吸収量の差, あるいは品 種固有の生理的・遺伝的形質のいずれかによって生じる ものと考えられる。

本実験では, 発芽前处理と子葉鞘期処理において品種 間差異が認められたが, 子葉䩗期処理は生育段階を温度 操作によって人為的に揃えた苗にたいして行ったことか ら，その原因が発芽の遅速に基ゔくものとは考え難い。 またイネの初期生育の速度および粐重と抵抗性の強さと の関係をしらべた結果 (表 2 )，その間に相関が認めら れなかった。

表 2 イネの生育の早さ扰よび粐重とベンチオカー ブにたいする抵抗性との関係

\begin{tabular}{|c|c|c|c|}
\hline 品 & 草 $(\mathrm{cm})^{\text {丈* }}$ & 千䊀 & 抵 抗 性** \\
\hline Rafaello & 12.4 & 26.8 & 大 \\
\hline キンマゼ & 13.8 & 26.7 & 大 \\
\hline C 4-63 & 14.2 & 26.9 & 小 \\
\hline ニホンハン & 14.7 & 27.2 & 犬 \\
\hline Bluebelle & 16.5 & 21.8 & 大 \\
\hline IR -8 & 17.8 & 28.2 & 小 \\
\hline Taichung Native & 18.1 & 23.7 & 小〜忺 \\
\hline Bluebonnet & 21.9 & 22.6 & 火 \\
\hline Leuang Tawng & 25.7 & 28.0 & 小 \\
\hline
\end{tabular}

注）*：播檑 15 月後 **: 発芽前処理

以上の結果から，ベンチオカーブにたいするイネの抵 抗性の品種間差異は, 品種固有の生理的 - 遺伝的形質に よるものと考えられる。

図 2 は IR-8 とニホンバレのベンチオカーブおよびシ メトリンにたいする耐性を比較したものである。ベンチ オカーブの処理による生体重の $90 \%$ 阻害薬量を比較す ると, 発芽前ではニホンバレが IR-8にくらべて約 2 倍 の耐性を示すが， 2 葉期では両品種とも同程度の耐性を 示した。一方, 同様の数值をシメトリンについてみる と, 発芽前・ 2 葉期処理ともニホンバレは IR-8 にくら ベて2 倍の耐性を示した。

KIM ら ${ }^{10)}$ は， ベンチオカーブとシメトリンの混合剤 をイネの生育期に用いると, 日本型の Jinheung よりも

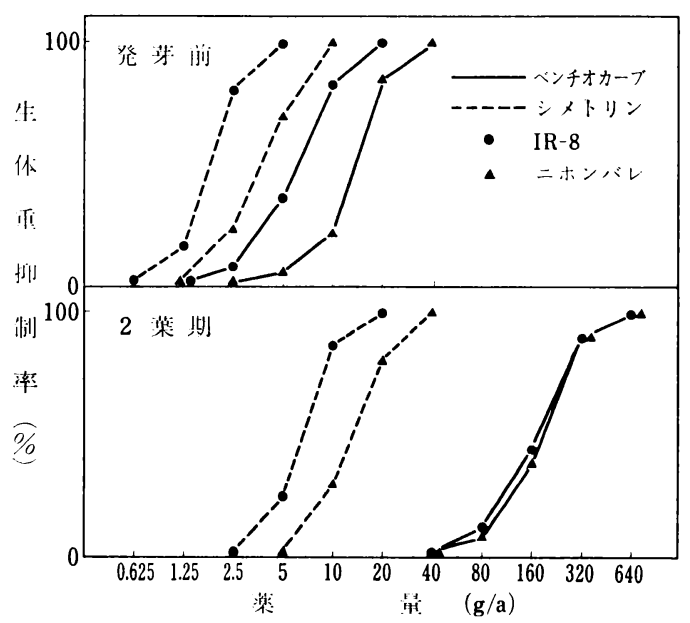

図 2 ベンチオカーブとシメトリンにたいするイネの 抵抗性

日本型とインド型の交配品種である Tongil にたいして 薬害の強いことを報告しているが，この実験結果は，こ のような抵抗性の品種間差異がシメトリンの特性により 生じることを示している。同時に，シメトリンを含有す る除草剤のインド型品種への適用に際しては, イネと雑 草間の選択活性に関する検討がきわめて重要であること を示唆している。

\section{3. 摘}

要

（1）わが国抢よび諸外国において栽培されている 34 品種のイネを供試して, ベンチオカーブにたいする抵 抗性の品種間差異について検討した。

a ）発芽前および子葉鞘期では，インド型の品種は,

日本，アメリカ，イタリアなどで栽培されている品 種にくらべて抵抗性が低い。

b ） 2 葉期では品種間差異が認められない。

c ）このような抵抗性の差異は品種固有の生理的・遺 伝的形質により生じるものと考えられる。

（2）シメトリンにたいするイネの抵抗性をみると， インド型の IR-8 は, 発芽前および 2 葉期とも日本型の ニホンバレにくらべて抵抗性が低い。

\section{引用 文 献}

1) Goto, M: Proceedings of the 4th Asian-Pacific Weed Science Society Conference. 124 (1973).

2) Schooler, A. B., A.R. Bell and J.D. NalewaJa: Weed Sci. 20, 167 (1972).

3) Osgood, R. V., R. R. Romanowski and H. W. Hilton: Weed Sci. 20, 537 (1972).

4) StAFFORD, R.E., V.E. Comstock and J.H. Ford: Crop Sci. B, 423 (1968)

5) Scott, G.E. and C. U. Grogan: Crop Sci. 9, 669 (1969).

6) Grogan, C.O., E.F. Eastin and R. D. Palmer: Crop Sci. 
3, 451 (1963).

7) 松中昭一：植物の化学調節 5 (2), 155 (1970).

8) Hayes, J. D., R. K. Pfeiffer and M. S. Rana: Weed Res. 5, 191 (1965)

9）而松昭二. 杰島建治・木村一郎：日本雑草防除研究会第 10 回講演 全: 宸旨. 54 (1971).
10) KIM, K. U., S. B. AHn and M. MiYahaRA: Abstracts 5th Asian-Pacific Weed Science Society Conference. 78 (1975).

11）一前富正・近内誠登・竹松拆夫：日木雑草防除研究会第 14 回講演 会要旨. 107 (1975).

(1976年:3 月 29 日受付)

\title{
Varietal Difference in the Tolerance of Rice Plants to Benthiocarb and Simetryne
}

\author{
Nobumasa ICHIZEN
}

Weed Control Res. Inst., Utsunomiya University, Utsunomiya

\section{Summary}

Thirty-four varieties of rice plants under flooded condition were treated by benthiocarb. At the emergence stage, IR-8, Leuang Tawng and C4-63 were very sensitive, and Taichung Native was a little sensitive. But twenty-four varieties of rice plants cultivated in Japan and Tainan-3, Bluebonnet, Bluebelle, Caluro, Calrose and Rafacello were tolerant to benthiocarb. At the 2-leaf stage, every variety was very tolerant to benthiocarb. Therefore, it was considered that Indica was more sensitive to benthiocarb than the other varieties.

IR-8 (Indica) was mone sensitive to simetryne than Nihonbare (Japonica) at the emergence stage and 2-leaf stage. 